\title{
МЕТОДИКА ДІАГНОСТИЧНОГО ТА ІДЕНТИФІКАЦІЙНОГО ДОСЛЦДЖЕННЯ ЗБРОЇ ЗА Ії̈ СЛІДАМИ НА ТІЛІ ПІДОЗРЮВАНОЇ ОСОБИ
}

\begin{abstract}
БАРАНЯК Володимир Михайлович - кандидат хімічних наук, доцент, доцент кафедри кримінального права і процесу Інституту права, психології та інноваційної освіти Національного університету «Львівська політехніка»
\end{abstract}

DOI 10.32782/LAW.UA.2020.3.17

Розглянуті можливості використання дифбузно-контактного методу для встановлення бакту незаконного носіння вогнепальної зброї за ї слідами на долоні підозрюваної особи під час розслідування злочинів, пов'язаних з ї̈ застосуванням.

Проаналізовані методи ідентифікаиї особи за виявленими на поверхні зброї слідами пальиів рук та за наявністю продуктів згоряння пороху на тильній стороні кисті особи, що стріляла.

Розглянуті проблемні питання щодо виявлення слідів застосування вогнепальної зброї у куриів та слідів металізащиї на долоні від поверхні корпусу ручної гранати $\Phi-1$.

Приведені експериментальні результати застосування методики встановлення групової належності зброї $і$ можливості ї ідентифікацї.

Ключові слова: сліди вогнепальноӥ зброй, механізм утворення слідів, дифузно-контактний метод, групова належність зброї, ідентибікачія зброї.

\section{Вступ}

Конституція України визначає як найвищу соціальну цінність людину іï життя, здоров'я, честь і гідність, недоторканність і безпеку [1]. Тільки за умов захисту особи від кримінальних правопорушень, охорони прав, свобод та законних інтересів учасників кримінального провадження можливе виконання завдань кримінального судочинства [2].
У Кримінальному кодексі України передбачено чимало злочинів, вчинення яких пов'язане із застосуванням вогнепальної зброї. Серед таких злочинів, спрямованих, зокрема, проти життя, здоров'я і власності громадян, громадської безпеки та порядку, слід відзначити умисне вбивство (ст. 115 КК), розбій (ст. 187 КК), погроза вбивством (ст. 129 КК), бандитизм (ст. 257 КК), хуліганство (ст.296 КК) [3].

Незаконне носіння, зберігання, ремонт, придбання, виготовлення або збут вогнепальної зброї без належного дозволу утворює окремий склад злочину, кримінальна відповідальність за вчинення якого передбаченаст. 263 КК України [3].

У зв’язку з цим, на практиці часто виникає необхідність встановити факт носіння і зберігання вогнепальної зброї. Носіння зброї особою може бути встановлено під час проведення особистого обшуку, огляду речей та одягу особи, огляду трупа або освідування в порядку? передбаченому ст.ст. 236, 237, 238, 241 Кримінального процесуального кодексу України [2].

На цей факт вказують: наявність самої зброї, а також сліди у вигляді нашарувань частинок металів, іржі, мастильних матеріалів або відбитків деталей зброї на одязі і тілі особи, сліди пострілу. Так, якщо за слідами пострілу на одязі і тілі підозрюваного встановлено, що постріл проведено з короткоствольної зброї, яка знаходилася під час пострілу під верхнім одягом, слідчий одночасно встановлює і факт носіння зброї цією особою, хоча під час огля- 


\section{Адміністративне право}

ду ( обшуку, освідування ) зброї у підозрюваного не було виявлено [4, с. 353].

Мета статті полягає у розкритті змісту та можливостей запропонованої нової методики, яка стосується діагностичного та ідентифікаційного дослідження зброї за їі слідами на тілі підозрюваної особи.

\section{Наукова дослідженість проблеми:}

У криміналістичній літературі питання встановлення факту зберігання та носіння вогнепальної зброї за їі слідами розглядається епізодично [4,с. 353; 5, с. 129]. У багатьох літературних джерелах, зокрема нових [6, с. 151, $161 ; 7$, c.], основну увагу зосереджено на встановленні факту застосування вогнепальної зброї за слідами, які залишені нею на тілі та одязі особи, що стріляла, на трупі та на різноманітних уражених зброєю перешкодах.

\section{ВикАад основного матеріалу}

Носіння і зберігання вогнепальної зброї $\mathrm{\epsilon}$ прикладами пасивного використання зброї, а тому розслідування такого злочину повинно бути особливо повним, всебічним i об'єктивним.

У зв'язку з цим, велике значення має проведення комплексних експертних досліджень у галузі судово-балістичної трасології, судової медицини, дактилоскопії, судової хімії.

За фактом носіння вогнепальної зброї ідентифікація особи може здійснюватися за виявленими на поверхні зброї слідами пальців рук, а факт проведення пострілу - за наявністю продуктів згоряння пороху на тильній стороні кисті особи, що стріляла. Сліди пальців рук виявляють дактилоскопічними методами, а сліди кіптяви і незгорілих порошинок - якісною реакцією на нітрати з розчином дифеніламіну. Однак, виникає питання щодо особи курця, у якого під час і після куріння на поверхні кисті відкладаються нітрати, що містяться у сигаретному димі, i, вочевидь, маскують сліди від пострілу.

Нами запропонована методика виявлення і дослідження слідів металізації від ручної вогнепальної зброї на долоні умовно підозрюваної особи із застосуванням дифузно-контактного методу, а також встановлення системи, моделі зброї та її ідентифікації.
Ця методика розширює та доповнює фундаментальні трасологічні уявлення про характер утворення слідів і може бути основою для вивчення слідоутворення від різних видів зброї.

Об'єктами дослідження були вогнепальна зброя, яка має відкриту тильну сторону рукоятки (зі щічками), та долоня експериментатора. Для експерименту були відібрані пістолети ТТ (калібр 7, 62 мм), Беретта (калібр 9, 0 мм), МЦ (Марголіна) (калібр 5, 6 мм) і сигнальний пістолет-ракетниця СПШ (калібр 26, 0 мм).

Дослідження проводили за наступною методикою. Пістолет протягом приблизно 15 с утримували в руці, тричі натискаючи на спусковий гачок. Після цього, долоню 3 незначним зусиллям прикладали до аркуша відфіксованого фотопаперу, який попередньо був зволожений 25-процентним розчином оцтової кислоти. Отриманий відбиток проявляли $1 \%$-ним водним розчином діетилдітіокарбамату натрію, який утворює стійкі комплексні сполуки з іонами заліза. Під час проявлення спостерігали утворення зображення слідів від металевої частини рукоятки зброї, які виявились співрозмірними із шириною рукоятки зброї. На зображеннях також зберігається відстань від краю рукоятки до центру гвинтів (заклепок) кріплення щічок. На контактограмах сліди утворювались незалежно від того, у якій руці утримувалась зброя, а після проведеного пострілу з даної зброї вони відзначалися більшою чіткістю зображення внаслідок віддачі зброї. Також встановлено, що відбитки зброї на долоні зберігаються протягом 4 год при невимушеній поведінці експериментатора (такій, як тримання за поруччя у громадському транспорті, відкривання дверей за ручку замка, контакт з іншими металевими предметами).

На контактограмі, отриманій 3 пістолета Беретта, чітко проявилася будова його рукоятки. Крім основного сліду, спостерігається зображення металевої декоративної смужки завширшки 2, 5 мм, яка обрамляє контури щічок.

Під час вивчення слідів, утворених рукояткою пістолета Марголіна, крім родових ознак, були також виявлені індивідуальні ознаки, такі як ступінь закручування та напрямок розташування шліца головки гвинтів кріплення щічок.

Застосована методика дослідження дозволяє визначити модель зброї за такими гру- 
повими ознаками, як форма, будова, ширина рукоятки та місце розташування гвинтів кріплення щічок рукоятки зброї.

Проблемним залишається питання щодо механізму утворення слідів як наслідок розчинення металу рукоятки зброї у потожировій речовині долоні, тертя контактуючих поверхонь або їх комбінованої дії. Для вирішення цього питання проводились дослідження екранованої шкіряною рукавицею поверхні долоні, у яку вкладали зброю. На отриманій контактограмі спостерігали відбитки металевої частини рукоятки зброї, що дає підстави стверджувати їх утворення внаслідок тертя контактуючих поверхонь.

Отже, за результатами проведених досліджень утворення відбитків зброї на долоні можна розглядати як результат комбінованої дії, яка полягає у розчиненні металу рукоятки у потожировій речовині долоні і терті контактуючих поверхонь. Для підтвердження цієї гіпотези проводились експерименти з навчальною гранатою Ф-1 3 частково відсутнім лакофарбовим покриттям поверхні їі корпусу. Вибір для дослідження цього виду зброї зумовлений усе частішим використанням ручних бойових гранат (Ф-1, РГД-5) у злочинних цілях та у побутових конфліктах.

Дослідження проводили за методикою дослідження слідів від вогнепальної зброї.

У результаті дослідження на контактограмі будь-які сліди від корпусу гранати були відсутні, що можна пояснити різним ступенем розчинності матеріалу (чавун) корпусу гранати i рамки (сталь) вогнепальної зброї в органічних кислотах і солях, що входять до складу потожирової речовини долоні. У цьому випадку пояснити отримання відбитків внаслідок тертя контактуючих поверхонь за аналогією з попередніми дослідженнями виявилось неможливим.

Дослідження механізму утворення слідів від зброї на поверхні долоні трупа особи також дало б можливість вирішити деякі проблемні питання, які пов’язані з інсценуванням самогубства із застосуванням вогнепальної зброї.

\section{Висновки}

Таким чином, описана вище методика дає можливість встановити факт незаконного но-
Considered the possibilities of the use of diffuse-contact method are considered with the purpose of establishment the fact of the illegal carrying of a firearm according to its tracks on the palm of the suspected person at investigation of crimes related to its application.

Methods of identification of the person by fingerprints found on the surface of the weapon and by the presence of gunpowder combustion products on the back of the shooter's hand are analyzed.

The problematic issues concerning the detection of traces of the use of firearms in smokers and traces of metallization on the palm from the surface of the body of a hand grenade F-1 are considered.

The experimental results of application of the offered method are resulted for establishment of group belonging of a firearm and possibility of its authentication.

Key words: tracks of a firearm, mechanism of formation of tracks, diffuse-contact method, group belonging of a firearm, authentication of a firearm.

сіння та застосування вогнепальної зброї, а в окремих випадках - ідентифікувати зброю.

\section{Мiтература}

1. Конституція України : офіц. текст. Київ : КМ, 2013. 96 с.

2. Кримінальний процесуальний кодекс України : офіц. текст. Київ : Паливода А.В., 2012. 382 с.

3. Кримінальний кодекс України : наук.практ. коментар / за ред. М. I. Мельника, М. І. Хавронюка. Київ : Каннон, А.С.К., 2001. $1104 \mathrm{c}$.

4. Криминалистика : учеб. для вузов / под ред. проф. Р. С. Белкина и проф. И. М. Аузгина]. Москва : РИО МВД СССР,1978. T.1. 383 c.

5. Криминалистика : учеб. / под ред. проф. А. Г. Филиппова ( отв. ред.) и проф. А. Ф. Волынского. Москва : Спарк, 1998. 543 с.

6. Криміналістика : підруч. / за заг. ред. акад. П. Д. Біленчука]. Київ : АТІКА, 2001. 542 c.

7. Криминалистика : учеб. для вузов / под ред. Р. С. Белкина]. Москва : НОРМА ИНФРАМ, 1999. 990 с. 